\title{
THE RESEARCH OF HEAVY METALS AND PHYSICO-CHEMICAL ANALYSES OF DRAINING WATERS IN PEJA'S LANDFILL
}

\author{
Nexhdet Shala ${ }^{1}$, Arian Gashi ${ }^{2 *}$, Jetmir Prekalla ${ }^{3}$, Arsim Elshani ${ }^{4}$ \\ ${ }^{1,4}$ University "Haxhi Zeka" Str. UÇK, 30000 Peja, Kosovo; \\ ${ }^{2 *}$ Member of the Committee for Environmental Protection "Municipality of Peja" Str. Hasan Prishtina, Kosovo; \\ ${ }^{3}$ Future Environment of Kosovo Str. Sali Çeku no. 7, Peja, Kosovo; \\ *Corresponding Author Arian Gashi, e-mail: arigashi05@gmail.com;
}

Received September 2020; Accepted October 2020; Published November 2020;

DOI: https://doi.org/10.31407/ijees10.417

\begin{abstract}
Since ancient times, waste has been burned, reused or deposited without any management criteria. Taking into account all these very harmful elements for the environment, the aim is to research the content of drainage water, and the problem of waste disposal in the regional landfill of Peja to be done according to EU standards, and to ensure minimal environmental impact. A total of 4 samples were taken in this scientific work, in two time periods, divided into two in June, and two in September, where we analyzed them with two different methods of determining heavy metals, which for the purpose have to be compared among themselves based on the presence of heavy metal values and physic-chemical analysis in the Peja landfill. Waste collection is one of the most serious problems of civilization from the municipal point of view, as well as from the commercial, sanitary-epidemiological, construction, hydrological and technological aspects.
\end{abstract}

Key words: heavy metals, landfill, pollutants, waste collection. 